Article

\title{
Chemical Composition of the Essential Oil from Aerial Parts of Javanian Pimpinella pruatjan Molk. and Its Molecular Phylogeny
}

\author{
Agustina D. R. Nurcahyanti ${ }^{1}$, Issam J. Nasser ${ }^{2}$, Frank Sporer ${ }^{1}$, Jürgen Graf ${ }^{3}$, \\ Nurliani Bermawie ${ }^{4}$, Jürgen Reichling ${ }^{1}$ and Michael Wink ${ }^{1, *}$ \\ 1 Institute of Pharmacy and Molecular Biotechnology, Heidelberg University, Im Neuenheimer Feld 364, \\ Heidelberg D-69120, Germany; adr.nurcahyanti@gmail.com (A.D.R.N.); frank.sporer@gmx.de (F.S.); \\ juergen.reichling@urz.uni-heidelberg.de (J.R.) \\ 2 College of Health and Medical Technology, Middle Technical University, Baghdad 10047, Iraq; \\ issam788@yahoo.com \\ 3 Institute of Organic Chemistry, Heidelberg University, Im Neuenheimer Feld 270, Heidelberg D-69120, \\ Germany; graf@oci.uni-heidelberg.de \\ 4 Department of Plant Genetic Resources and Breeding, Indonesian Spice and Medicinal Crops \\ Research Institute, Indonesian Agency for Agricultural Research and Development (IAARD), \\ Jl. Tentara Pelajar No.3A, Bogor 16111, Indonesia; nurlianib@yahoo.com \\ * Correspondence: wink@uni-heidelberg.de; Tel.: +49-6221-544-880
}

Academic Editor: Ipek Kurtboke

Received: 12 March 2016; Accepted: 11 July 2016; Published: 14 July 2016

\begin{abstract}
The species-rich and diverse genus Pimpinella is mainly distributed in Europe and Asia; a few species occur in Africa. Yet, the Javanian Pimpinella, P. pruatjan, which has been used as an aphrodisiac in Indonesian traditional medicine, was studied for the first time in the context of chemical composition, as well as phylogeny analysis and antimicrobial activity. We examined the chemical composition of the essential oil (EO) from aerial parts of P. pruatjan by gas liquid chromatography-mass spectrometry (GLC-MS). The main component of EO was (Z)- $\gamma$-bisabolene. Several oxygenated monoterpenes, oxygenated sesquiterpenes, and sesquiterpenes were also detected. The genetic relationship of Pimpinella pruatjan Molk. to other Pimpinella species was reconstructed using nucleotide sequences of the nuclear DNA marker ITS (Internal Transcribed Spacer). P. pruatjan clusters as a sister group to the African Pimpinella species. The EO did not exhibit an apparent antimicrobial activity.
\end{abstract}

Keywords: Pimpinella pruatjan Molk.; essential oil (EO); GLC-MS; ITS; phylogeny; antimicrobial

\section{Introduction}

Pimpinella is a member of the family Apiaceae and comprises approximately 200 species occurring in Europe, Asia, and some species in Africa [1-3]. Pimpinella pruatjan Molk. (formerly Pimpinella alpina) is an indigenous Pimpinella species to the Indonesian island Java [4,5]. The plant grows in restricted areas of the Dieng Plateau, Central Java [6,7], on the Pangrango mountain in West Java, and in the mountain area in East Java [8]. The root of P. pruatjan has been used as an aphrodisiac in Indonesia traditional medicine (Jamu). No medicinal uses have been reported from the aerial parts of this plant. In this study, we also examined the essential oils from the aerial part to investigate whether the oils possess antimicrobial activity as can be seen in other Pimpinella species.

The genus Pimpinella is known for its essential oils (EOs) [2,9-11]. The oils from Pimpinella species growing across Europe and Asia usually consist of monoterpenes (such as limonene, sabinene, $\alpha$-pinene, $\beta$-pinene, $\gamma$-terpinene), norsesquiterpenes (geijerene, pregeijerene), sesquiterpenes 
(such as himachalene, $\delta$-elemene, $\beta$-bisabolone, caryophyllene, germacrene $D$ ), and a high content of phenylpropanoid derivatives with the 2-hydroxy-5-methoxy-1-(E)-propenylbenzene skeleton, known as pseudoisoeugenol [1-3,12-14]. The presence of pseudoisoeugenol is an important chemosystematic character in the genus of Pimpinella and most likely contributes to the antimicrobial activity of the EOs $[2,15]$.

The EO from aerial parts of P. pruatjan has not been studied before nor its chemical composition and the phylogenetic position within the genus Pimpinella. We investigated the composition of the EO by GLC-MS and assessed its antimicrobial activity. The phylogeny of P. pruatjan was reconstructed using nucleotide sequences of the nuclear DNA marker ITS which is widely used in plants.

\section{Experimental Section}

\subsection{The Plant Material and Isolation of the Oils}

Plant material was collected from a mountain area in West Java, Indonesia, at an altitude of $>1800 \mathrm{~m}$ above sea level, in April-May 2011. Botanical identification was carried out by Deden Girmansyah, M.S., at the Research Centre for Biology, Indonesian Institute of Sciences, Bogor, Indonesia. A voucher specimen was deposited at the Indonesian Spice and Medicinal Crops Research Institute, Indonesian Agency for Agricultural Research and Development (IAARD). For this study, the plant has been registered in the botanical collection of the Biology Department, Institute of Pharmacy and Molecular Biotechnology, Heidelberg University, under the accession number P8259.

Dried aerial parts $(1 \mathrm{~kg})$ of P. pruatjan were crushed, followed by hydrodistillation for $3 \mathrm{~h}$ in a Clevenger-type apparatus to obtain the volatile oil. The EO was then dried over anhydrous sodium sulfate, evaporated in a Rotavapor, and stored in sealed vials at $4{ }^{\circ} \mathrm{C}$ for further analysis. The dried aerial parts contained about $0.23 \%$ of EO, calculated on dry weight base.

\subsection{Gas Liquid Chromatography—Mass Spectrometry (GLC-MS)}

Hexane solutions of the volatile oils were examined using GLC-MS on an HP5890 Series II gas chromatograph equipped with an DB- 5 capillary column $(30 \mathrm{~m} ; 0.25 \mathrm{~mm}$ inner diameter; $0.25 \mu \mathrm{m}$ film thickness) and used mass range and scan-time of mass spectra analysis. The injector was operated at a $250{ }^{\circ} \mathrm{C}$ in split mode (1:50) at a head pressure of $15 \mathrm{kPa}$ of Helium. The temperature program started with an isothermal step at $40{ }^{\circ} \mathrm{C}$ for $2 \mathrm{~min}$. The temperature was then raised to $300{ }^{\circ} \mathrm{C}$ at a rate of $4{ }^{\circ} \mathrm{C} / \mathrm{min}$ and held for $10 \mathrm{~min}$. A mixture of $\mathrm{n}$-alkanes $\left(\mathrm{C}_{8}-\mathrm{C}_{28}\right)$ was co-chromatographed with the samples to get the Kovats retention index (RI) of the separated compounds. The GLC was coupled to a quadrupole mass spectrometry SSQ 7000 (Thermo-Finnigan). The mass spectra were recorded at $70 \mathrm{eV}$ at a source temperature of $175{ }^{\circ} \mathrm{C}$, with the Xcalibur vers.1.3 software. The peaks were identified by comparing their mass spectra and retention indexes (RI) relative to $\mathrm{C}_{8}-\mathrm{C}_{28} \mathrm{n}$-alkanes, the values of our internal library, NIST and literature data $[2,16,17]$.

\subsection{DNA Barcoding of P. pruatjan}

DNA was isolated from aerial parts of P. pruatjan using the standard CTAB method with slight modification [18]. The ITS region was amplified with the primer pairs ITS forward ( $5^{\prime}$-GGAAGTAAAAGTCGTAACAAGG-3') and ITS reverse (5'-TCCTCCGCTTATTGATATGC-3'). DNA amplification buffer contained $5 \mu \mathrm{L}$ of $10 \times$ high PCR buffer, $1.5 \mathrm{~mL}$ of dNTP mixture containing $2.5 \mathrm{mM}$ each nucleotide, $1 \mu \mathrm{L}$ of each primer from $10 \mathrm{pmoL} / \mathrm{mL}$ stock, $0.5 \mu \mathrm{L}$ of $10 \mathrm{mg} / \mathrm{mL}$ BSA, $0.2 \mu \mathrm{L}$ of Top-TAQDNA Polymerase (2.0 U/mL, BIORON), 1-3 $\mu \mathrm{L}$ of template DNA, and sterile water was used to bring to total volume of $50 \mu \mathrm{L}$. The amplification was performed using a thermocycler (Tprofessional Basic Gradient, Biometra, Analytik Jena, Goettingen, Germany) under the following conditions: initial denaturation at $94^{\circ} \mathrm{C}$ for $1 \mathrm{~min}$, followed by 38 cycles of denaturation of double-stranded template DNA at $94^{\circ} \mathrm{C}$ for $50 \mathrm{~s}$, annealing at $55^{\circ} \mathrm{C}$ for $1 \mathrm{~min}$, and extension at $72{ }^{\circ} \mathrm{C}$ for $2 \mathrm{~min}$. After 38 cycles, DNA amplifications were followed by a final extension at $72{ }^{\circ} \mathrm{C}$ for $10 \mathrm{~min}$. Four $\mu \mathrm{L}$ of PCR product 
were analyzed by electrophoresis using $1 \%$ TAE agarose gels. The remaining PCR product was purified for direct sequencing (by company StarSEQ, Mainz, Germany).

Data analysis and reconstruction of phylogenetic tree were carried out as described before [19]. The aligned ITS sequence from P. pruatjan was compared with ITS sequences from 39 Pimpinella species retrieved from National Center for Biotechnology Information (www.ncbi.nlm.nih.gov). The sequence matrix was manually aligned using BioEditV 708. Genetic distances were determined using MEGA 7.0 using the Kimura 2-Parameter (K2P) model.

The evolutionary history was inferred by using the Maximum Likelihood method based on the Tamura-Nei model [20]. The tree with the highest log likelihood (-3088.5028) is shown. The percentage of trees in which the associated taxa clustered together is shown next to the branches. Initial tree(s) for the heuristic search were obtained automatically by applying Neighbor-Join and BioNJ algorithms to a matrix of pairwise distances estimated using the Maximum Composite Likelihood (MCL) approach, and then selecting the topology with superior log likelihood value. A discrete Gamma distribution was used to model evolutionary rate differences among sites $(5$ categories $(+G$, parameter $=6.4064)$ ). The rate variation model allowed for some sites to be evolutionarily invariable $([+I], 43.3441 \%$ sites). The tree is drawn to scale, with branch lengths measured in the number of substitutions per site. The analysis involved 40 nucleotide sequences. Codon positions included were 1st +2 nd +3 rd + Noncoding. There were a total of 599 positions in the final dataset. Evolutionary analyses were conducted in MEGA7 [21].

\subsection{Antimicrobial Activity}

\subsubsection{Microorganisms}

The antimicrobial activity of the EO was examined using Gram-positive bacteria, including Bacillus subtilis ATCC 6051, Staphylococcus aureus ATCC BAA-977, Streptococcus pyogenes ATCC 12344, Staphylococcus epidermis ATCC 14990, Enterococcus faecalis ATCC 51299 VRE Neg, vancomycin resistant Enterococcus faecalis ATCC 51299 VanB, and methicillin-resistant Staphylococcus aureus NTCC 10442; Gram-negative bacteria included Escherichia coli ATCC 25922, Pseudomonas aeruginosa ATCC 27853, and Klebsiella pneumoniae ATCC 700603; and yeast, including Candida albicans ATCC 90028, Candida parapsilosis ATCC 22019, and Candida glabrata ATCC MYA-2950. All of the microorganism cultures were supplied by Medical Microbiology Laboratory, Hygiene Institute, Heidelberg University, Heidelberg, Germany.

\subsubsection{Culture Preparation and Cultivation of Microorganism}

Bacterial cultures were sub-cultured in Columbia medium with $5 \%$ sheep blood (Becton Dickinson, Heidelberg, Germany), Mueller-Hinton broth (MHB) (Fluka), and brain heart infusion (BHI) (Merck, Heidelberg, Germany), and incubated at $37^{\circ} \mathrm{C}$ for $24 \mathrm{~h}$, with the supply of $\mathrm{CO}_{2}$ well-maintained in cultivation of Streptococcus pyogenes. Fungal cultures were sub-cultured in CHROMagar Candida (Becton Dickinson, Heidelberg, Germany) and incubated at $25^{\circ} \mathrm{C}$ for $48 \mathrm{~h}$.

Bacterial or fungal colonies from $24 \mathrm{~h}$ or $48 \mathrm{~h}$ cultures were suspended to a $0.5 \mathrm{McF}$ arland turbidity $\approx 1 \times 10^{8}$ colony forming unit per $\mathrm{mL}(\mathrm{CFU} / \mathrm{mL})$. For the antimicrobial assay, the turbidity of bacterial or fungal solution was then adjusted to the concentration of $1 \times 10^{5}(\mathrm{CFU} / \mathrm{mL})$.

\subsubsection{Determination of Minimum Inhibitory Concentration (MIC) and Minimum Microbicidal Concentration (MMC)}

MIC was determined by the micro dilution method according to NCCLS (2006) [22]. Samples were diluted in DMSO to give a stock solution concentration of $200 \mathrm{mg} / \mathrm{mL}$. Serial concentrations were made to obtain a final concentration of 10 to $8 \times 10^{-2} \mathrm{mg} / \mathrm{mL}$ and placed in a 96-well plate (Greiner Bio-one, Frickenhausen, Germany). A suspension of bacterial or fungal cells with a concentration of $1 \times 10^{5}(\mathrm{CFU} / \mathrm{mL})$ was then added and 96-well plates were incubated at $37^{\circ} \mathrm{C}$ for $24 \mathrm{~h}$ for bacteria and at $25^{\circ} \mathrm{C}$ for $48 \mathrm{~h}$ for yeast. MIC was defined as the lowest concentration that showed no visible turbidity. The observation was directly visualized without coloring reagent such as tetrazolium or 
Alamar blue and directly compared to the negative growth control containing no bacteria and positive growth control containing bacteria. MMC was determined by inoculating $3 \mu \mathrm{L}$ from each clear well and incubated at $37^{\circ} \mathrm{C}$ for $24 \mathrm{~h}$ for bacteria and at $25^{\circ} \mathrm{C}$ for $48 \mathrm{~h}$ for yeast. The MMC value was defined as the lowest concentration of samples that showed no growth of bacteria or yeast after incubation. Streptomycin and vancomycin (Applichem, purity $>93 \%$ ) with the highest tested concentration of $50 \mu \mathrm{g} / \mathrm{mL}$ were used as a positive control against bacteria and nystatin (Cellpharm, purity $>90.6 \%$, concentration $50 \mu \mathrm{g} / \mathrm{mL}$ ) against yeast.

\section{Results and Discussion}

\subsection{Relationships between P. pruatjan and Other Pimpinella Species}

ITS sequences of P. pruatjan were used for DNA barcoding and to investigate the genetic relationship of $P$. pruatjan with other Pimpinella species distributed in Europe, Asia, and Africa. The phylogenetic analyses were based on a representative sampling of the genus Pimpinella, which includes 16 accessions from Africa and Madagascar and 26 from Eurasia. Another Apiaceae, Foeniculum vulgare served as an outgroup for the phylogeny reconstruction.

The phylogeny reconstruction reveals four major clades, supported with high bootstrap values (Figure 1). P. pruatjan clusters in a clade of Eurasian taxa as a sister group to the African samples with high bootstrap support (Figure 1). This finding could suggest that P. pruatjan might share phytochemical characteristics with the African Pimpinella species. European and Asian Pimpinella species have significant biological activities, such as antifungal [23], antiviral [24], and anticonvulsant effects in mice [25]. Unfortunately, no report could be found so far about the biological activity of African Pimpinella species.

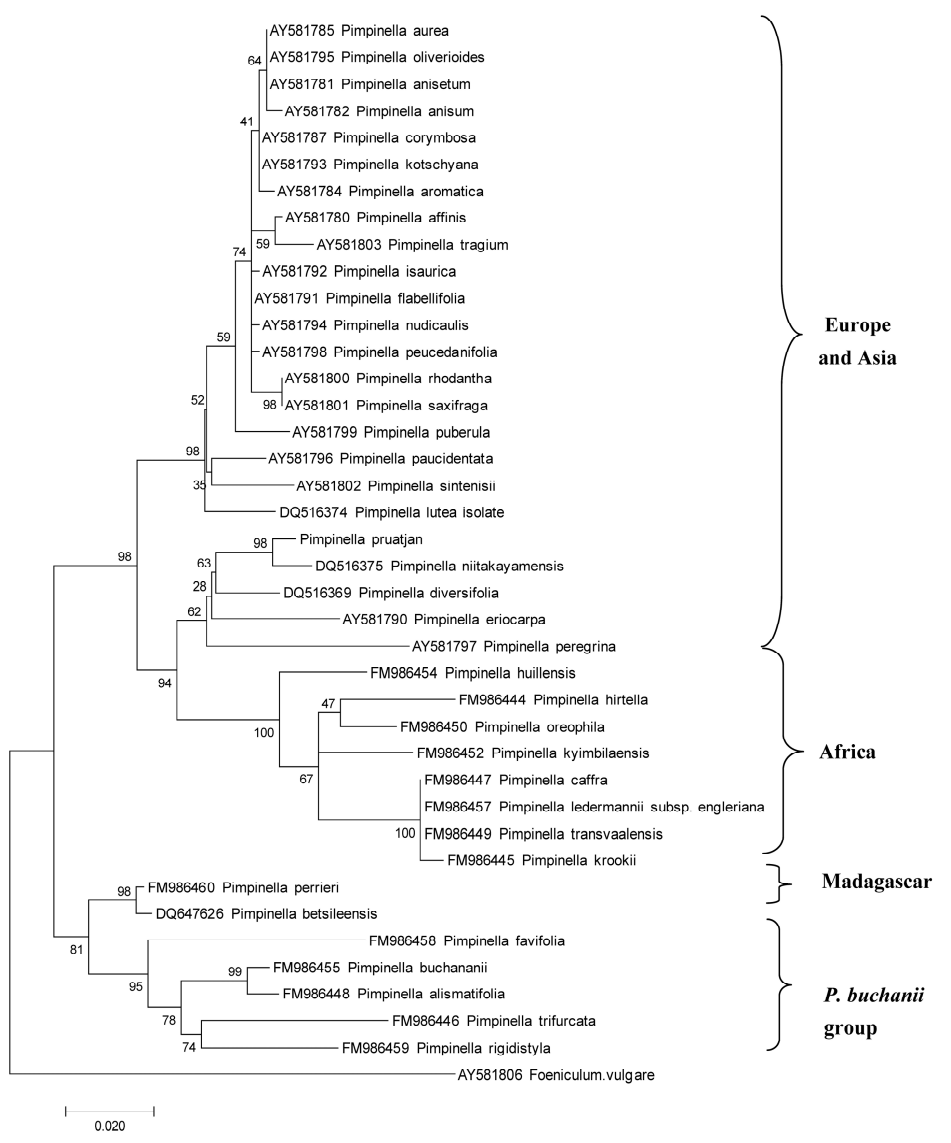

Figure 1. Molecular Phylogenetic analysis of Pimpinella pruatjan and the connection to the African species by Maximum Likelihood method. Numbers at the nodes are Bootstrap values from 500 replications. 


\subsection{Chemical Composition of the Essential Oil}

Table 1 summarizes the components of the volatile oil from the aerial parts of P. pruatjan, their retention indices, and their relative abundances. The EO consists of oxygenated monoterpenes, sesquiterpenes, oxygenated sesquiterpenes, and arylpropanoids (derivatives of pseudoisoeugenol). Twenty secondary metabolites could not be identified; they could be primary or secondary metabolites. The main component was (Z)- $\gamma$-bisabolene (25.28\%). Several oxygenated monoterpenes, such as linalool oxide, linalool, verbenol, borneol, p-cymen-8-ol, $\alpha$-terpineol, trans-caren-2-ol, thymol, carvacrol, and $p$-vinyl guaiacol were detected at concentrations ranging from $0.1 \%$ to $1.2 \%$. Three monoterpenes were detected, namely $p$-cymene, $\gamma$-terpinene, and p-cymenene. Sesquiterpenes, which are normally shared among the genus Pimpinella, were also discovered, such as $\alpha$-cubebene, $\alpha$-copaene, $\beta$-cubebene, $\beta$-elemene, and ar-curcumene. A number of oxygenated sesquiterpenes, such as dictamnol, caryophyllene oxide, humulene epoxide II, $\alpha$-cadinol, and amorpha-4,9-dien-2-ol were also identified at concentrations ranging from $0.1 \%$ to $2.8 \%$. The important chemosystematic characters in the genus Pimpinella, geijerene and the pseudoisoeugenol could also be detected albeit in low quantities (Table 1).

Table 1. Chemical composition of aerial part essential oils(Eos) from P. pruatjan.

\begin{tabular}{|c|c|c|c|c|c|}
\hline No. & Identified Compounds & $\mathbf{R I}^{*}$ & RI [15] and Ref. & Abundance (\%) * & Identification \\
\hline 2 & 3-Methylcyclopentanol & 835 & $836[27]$ & 0.25 & MS \\
\hline 3 & Heptanal & 891 & 902 & 0.12 & MS, RI \\
\hline 5 & Nonane (n) & 902 & 900 & 3.70 & MS, RI \\
\hline 6 & Unidentified II & 914 & & 0.12 & \\
\hline 7 & 2,2-Dimethylpentanal & 920 & $826[28]$ & 4.53 & MS \\
\hline 10 & Unidentified V & 943 & & 1.93 & \\
\hline 11 & Unidentified VI & 955 & & 2.76 & \\
\hline 12 & Isopropyl tiglate & 968 & 976 & 6.92 & MS, RI \\
\hline 13 & Unidentified VII & 994 & & 0.38 & \\
\hline 14 & Unidentified VIII & 997 & & 0.50 & \\
\hline 15 & Octanal & 1003 & 998 & 0.25 & MS, RI \\
\hline 21 & trans-Linalool oxide & 1072 & 1072 & 0.11 & MS, RI \\
\hline 22 & p-Cymenene & 1089 & 1091 & 0.18 & MS, RI \\
\hline 23 & 2-Nonanone & 1093 & 1090 & 0.10 & MS, RI \\
\hline 24 & Linalool & 1101 & 1096 & 0.20 & MS, RI \\
\hline 25 & Nonanal & 1105 & 1100 & 0.12 & MS, RI \\
\hline 26 & Geijerene & 1141 & 1143 & $\operatorname{Tr}$ & MS, RI \\
\hline 27 & trans-Verbenol & 1149 & 1144 & 0.18 & MS, RI \\
\hline 28 & (E)-2-Nonenal & 1160 & 1161 & 0.25 & MS, RI \\
\hline 29 & Borneol & 1165 & 1169 & 0.12 & MS, RI \\
\hline 30 & 2-Methoxy-3-(1-methylpropyl) pyrazine & 1172 & 1172 & $\operatorname{Tr}$ & MS, RI \\
\hline 31 & Terpinen-4-ol & 1176 & 1177 & 0.54 & MS, RI \\
\hline 32 & Octanoic acid & 1179 & 1171 & 0.16 & MS, RI \\
\hline 33 & $p$-Cymen-8-ol & 1184 & 1183 & 0.74 & MS \\
\hline 42 & 6-Hydroxy-m-anisaldehyde & 1295 & & 0.28 & MS \\
\hline 43 & Thymol & 1298 & 1290 & 0.13 & MS, RI \\
\hline 44 & Carvacrol & 1304 & 1299 & 0.37 & MS, RI \\
\hline 45 & 4-Ethenyl-2-methoxyphenol & 1315 & 1309 & 0.20 & MS, RI \\
\hline 46 & Unidentified XII & 1343 & & 0.14 & \\
\hline 47 & $\alpha$-Cubebene & 1353 & 1348 & 0.20 & MS, RI \\
\hline 48 & $\gamma$-Nonalactone & 1363 & 1361 & 0.14 & MS, RI \\
\hline 49 & 1-(4-Hydroxybenzylidine)acetone & 1367 & & 0.12 & MS \\
\hline 50 & $\alpha$-Copaene & 1379 & 1376 & 0.56 & MS, RI \\
\hline
\end{tabular}


Table 1. Cont.

\begin{tabular}{|c|c|c|c|c|c|}
\hline No. & Identified Compounds & $\mathbf{R I}^{*}$ & RI [15] and Ref. & Abundance $(\%) *$ & Identification \\
\hline 51 & 8-epi-Dictamnol & 1382 & 1380 & 0.53 & MS, RI \\
\hline 52 & $\beta$-Cubebene & 1387 & 1388 & 0.58 & MS, RI \\
\hline 53 & $\beta$-Elemene & 1394 & 1390 & 0.40 & MS, RI \\
\hline 55 & $\alpha$-Cedrene & 1418 & 1411 & 0.22 & MS, RI \\
\hline 56 & (E)-Caryophyllene & 1423 & 1419 & 1.12 & MS, RI \\
\hline 57 & 2,5-Dimethoxy-p-cymene & 1427 & 1426 & 4.39 & MS, RI \\
\hline 60 & $\alpha$-Himachalene & 1448 & 1451 & $\operatorname{Tr}$ & MS, RI \\
\hline 61 & allo-Aromadendrene & 1454 & 1460 & $\operatorname{Tr}$ & MS, RI \\
\hline 62 & $\alpha$-Humulene & 1458 & 1454 & 0.26 & MS, RI \\
\hline 63 & Sesquisabinene & 1461 & 1459 & 0.22 & MS, RI \\
\hline 64 & cis-Cadina-1(6)-4-diene & 1466 & 1463 & 2.86 & MS, RI \\
\hline 65 & Unidentified XIII & 1472 & & 0.14 & \\
\hline 71 & cis- $\gamma$-Bisabolene & 1518 & 1515 & 25.28 & MS, RI \\
\hline 72 & $\delta$-Cadinene & 1530 & 1523 & 1.10 & MS, RI \\
\hline 73 & Spathulenol & 1582 & 1578 & 0.13 & MS, RI \\
\hline 74 & Caryophyllene oxide & 1589 & 1583 & 2.80 & MS, RI \\
\hline 75 & Unidentified XIV & 1611 & & 0.23 & \\
\hline 76 & Humulene epoxide II & 1614 & 1608 & 0.96 & MS, RI \\
\hline 77 & Unidentified XV & 1625 & & 0.51 & \\
\hline 78 & 3-Thujopsanone & 1651 & 1654 & 0.14 & MS, RI \\
\hline 79 & $\alpha$-Cadinol & 1660 & 1654 & 0.54 & MS, RI \\
\hline 80 & Unidentified XVI & 1674 & & 0.22 & \\
\hline 81 & 14-Hydroxy-9-epi-(E)-caryophyllene & 1677 & 1669 & 0.24 & MS, RI \\
\hline 82 & Unidentified XVII & 1682 & & 0.12 & \\
\hline 83 & Amorpha-4,9-dien-2-ol & 1692 & 1700 & 0.46 & MS, RI \\
\hline 93 & Nezukol & 2141 & 2133 & 0.18 & MS, RI \\
\hline
\end{tabular}

There are important differences in main constituents of the $\mathrm{EO}$ among the members of the genus Pimpinella. For instance, P. aurea DC, growing in Iran, contains limonene in the EO of aerial parts, epoxy pseudoisoeugenyl-2-methylbutyrate in the EO of roots, and $\beta$-bisabolone in the $\mathrm{EO}$ of fruits $[2,3,29]$. Trans-anethole is the main component in EO of P. anisum and P. anisetum, but it cannot be found in other Pimpinella species, such as in P. peregrina L., P. tragium Vill ssp. polyclada (Boiss. \& Heldr.) Tutin, and P. affinis Ledeb [16]. (Z)- $\gamma$-Bisabolene, the main constituent in the aerial part EO of P. pruatjan, has not been found as a major compound in other EO of Pimpinella.

We detected a $\mathrm{C}_{17}$-polyacetylene, falcarinol (Figure 2) in the EO of P. pruatjan for the first time in the genus Pimpinella. Other polyacetylenes have been reported to be present in some Pimpinella species, such as those of pentadeca-2,4,6,8-tetraene, 2,8-decadiene-4,6-diene-1-al, 2,8-tridecadiene-4,6-diene-10-ol in P. major L., 2,8,10-tridecatriene-4,6-diene in P. major L. and P. anisum L., 2-tridecaene-4,6-diene-8-ol-10-on in P. major L. and P. saxifraga L. [30]. The pathway leading to polyacetylene is common to this genus and the occurrence of falcarinol is perhaps due to the modification of the polyacetylene biosynthesis or species specific of their enzymatic machinery. 


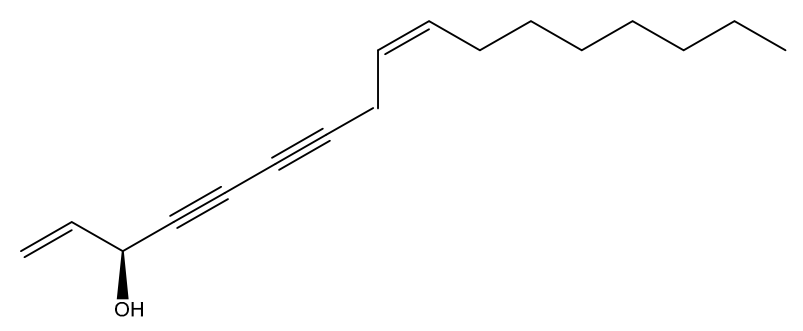

Figure 2. Falcarinol.

\subsection{Antimicrobial Activity}

The antimicrobial activity of the EO was examined against three Candida species and some pathogenic bacteria, including those with multidrug-resistance as representative for pathogenic bacteria causing human infection diseases. The $\mathrm{EO}$ exhibited no antibacterial or antifungal activity (at concentrations below $0.5 \mathrm{mg} / \mathrm{mL}$ ) against pathogenic bacteria, including multidrug resistant bacteria, MRSA and VRE. The known high and moderate antimicrobial activities in the genus Pimpinella is mainly due to the presence of epoxypseudoisoeugenol and their derivatives; in particular, species which contain high epoxypseudoisoeugenol concentrations showed high antimicrobial activity $[2,16]$. These secondary metabolites carry epoxide groups which are powerful electrophiles. They can react with nucleophilic groups (e.g., $\mathrm{NH}_{2}, \mathrm{NH}$, and $\mathrm{SH}$ groups of amino acid) in proteins and thus affect the biological system in microorganisms [2,31,32]. In the EO of P. pruatjan epoxypseudoisoeugenols are present in low amounts which would explain the absence of antibacterial activity as compared to some other Pimpinella species [2,16]. Polyacetylene, including falcarinol showed profound antimicrobial activity against several bacteria, such as Staphylococcus aureus, S. epidermidis, Micrococcus luteus and Enterococcus faecalis and multidrug resistant Staphylococcus aureus $[33,34]$. The presence of falcarinol in P. pruatjan in a low amount barely affects the antimicrobial activity.

\section{Conclusions}

In conclusion, this is the first study suggesting that, differing from most Eurasian species, Javanian species possess $(Z)-\gamma$-bisabolene as the main component in the essential oil and the presence of known falcarinol, which is not common in the Eurasian species. Javanian Pimpinella cluster as a sister to the African species together with a few Eurasian species. Further investigations of the phytochemistry pharmacology of African Pimpinella are needed to understand the evolutionary background of Pimpinella species across the world.

Acknowledgments: A.D.R.N. is thankful to the Deutscher Akademischer Austauschdienst (DAAD) for a PhD fellowship.

Author Contributions: A.D.R.N., M.W. conceived and designed the experiments; A.D.R.N., I.J.N., F.S., J.G. performed the experiments; N.B. collected and prepared the plant material; A.D.R.N., J.R., M.W. analyzed the data; MW contributed reagents/materials/analysis tools; A.D.R.N., M.W. wrote the paper.

Conflicts of Interest: The authors declare no conflict of interest.

\section{References}

1. Velasco-Negueruela, A.; Pérez-Alonso, M.J.; Pérez de Paz, P.L.; Vallejo, C.G.; Palá-Pául, J.; Iñigo, A. Chemical composition of the essential oils from the roots, fruits, leaves and stems of Pimpinella cumbrae Link growing in the Canary Islands (Spain). Flavour Fragr. J. 2002, 17, 468-471. [CrossRef]

2. Tabanca, N.; Bedir, E.; Ferreira, D.; Slade, D.; Wedge, D.E.; Jacob, M.R.; Khan, S.I.; Bedir, E.; Baser, K.H.; Khan, I.A. Bioactive constituents from Turkish Pimpinella species. Chem. Biodivers. 2005, 2, 221-232. [CrossRef] [PubMed] 
3. Delazar, A.; Biglari, F.; Esnaashari, S.; Nazemiyeh, H.; Talebpour, A.H.; Nahar, L.; Sarker, S.D. GC-MS analysis of the essential oils, and the isolation of phenylpropanoid derivatives from the aerial parts of Pimpinella aurea. Phytochemistry 2006, 67, 2176-2181. [CrossRef] [PubMed]

4. Lewis, W.H. Medicinal Botany; Wiley-Interscience: New York, NY, USA, 1977.

5. De Pasquale, A. Therapeutic and pharmacologic properties of the genus pimpinella. In Illicium, Pimpinella, and Foeniculum; Jodral, M.M., Ed.; CRC Press LLC: Boca Raton, FL, USA, 2004; pp. 167-197.

6. Rahardjo, M.; Sudiarto; Endjo, D.; Wahyuni, S.; Sukarman; Trisilawati, O.; Shusena, A.; Kosasih; Susi, N. Studi Teknologi Perbanyakan, Budidaya dan Konservasi ex Situ Tanaman Obat Langka Purwoceng (Pimpinela pruatjan Molkenb.); Balai Tanaman Obat dan Aromatik: Jawa Barat, Indonesia, 2004; pp. 277-292.

7. Syahid, S.F.; Rostiana, O.; Miftakhurohmah; Seswita, D.; Rosita; Darwati, I.; Surachman, D.; Aisyah, S. Teknik perbanyakan, produksi metabolit sekunder melalui kultur akar rambut purwoceng secara in vitro dan aklimatisasi di lapang. In Laporan Penyelesaian DIP Bagian Proyek Penelitian Tanaman Rempah dan Obat; Balittro: Bogor, Indonesia, 2004; pp. 128-142.

8. Darwati, I.; Roostika, I. Status penelitian Purwoceng (Pimpinella alpina Molk.) di Indonesia. Bul. Plasma Nutfah 2006, 12, 1-6.

9. Embong, M.B.; Hadziyev, D.; Molnar, S. Essential oil from spices grown in Alberta. Anise oil (Pimpinella anisum). Can. J. Plant Sci. 1977, 57, 681-688. [CrossRef]

10. Bakshu, L.M.; Raju, R.R.V. Essential oil composition and antimicrobial activity of tuberous roots of Pimpinella tirupatiensis Bal. \& Subr., an endemic taxon from eastern ghats, India. Flavour Fragr. J. 2002, $17,413-415$.

11. Velasco-Negueruela, A.; Pérez-Alonso, M.J.; Pérez de Paz, P.L.; Palá-Pául, J.; Sanz, J. Analysis by gas chromatography-mass spectrometry of the essential oil from the aerial parts of Pimpinella junoniae Ceb. \& Ort., gathered in La Gomera, Canary Islands, Spain. J. Chromatogr. A 2003, 1011, 241-244. [PubMed]

12. Bohn, I.; Kubeczka, K.H.; Schultze, W. The essential root oil of Pimpinella major. Planta Med. 1989, 55, 489-490. [CrossRef] [PubMed]

13. Askari, F.; Sefidkon, F. Volatile components of Pimpinella tragium Vill. from Iran. Iran. J. Pharm. Res. 2005, 2, 117-120.

14. Velasco-Negueruela, A.; Pérez-Alonso, M.J.; Pérez de Paz, P.L.; Palá-Pául, J.; Sanz, J. Analysis by gas chromatography-mass spectrometry of the essential oils from the aerial parts of Pimpinella anagodendron Bolle and Pimpinella rupicola Svent., two endemic species to the Canary Islands, Spain. J. Chromatogr. A 2005, 1095, 180-184. [CrossRef] [PubMed]

15. Tabanca, N.; Demirci, B.; Ozek, T.; Kirimer, N.; Baser, K.H.; Bedir, E.; Khan, I.A.; Wedge, D.E. Gas chromatographic-mass spectrometric analysis of essential oils from Pimpinella species gathered from Central and Northern Turkey. J. Chromatogr. A 2006, 1117, 194-205. [CrossRef] [PubMed]

16. Tabanca, N.; Bedir, E.; Kirimer, N.; Baser, K.H.; Khan, S.I.; Jacob, M.R.; Khan, I.A. Antimicrobial compounds from Pimpinella species growing in Turkey. Planta Med. 2003, 69, 933-938. [PubMed]

17. Adams, R.P. Identification of Essential Oil Components by Gas Chromatography/Mass Spectrometry; Allured Publishing Corporation: Carol Stream, IL, USA, 2007.

18. Khanuja, S.P.S.; Shasany, A.K.; Darokar, M.P.; Kumar, S. Rapid isolation of DNA from dry and fresh samples of plants producing large amounts of secondary metabolites and essential oils. Plant Mol. Biol. Rep. 1999, 17, 1-7. [CrossRef]

19. Herrmann, F.; Wink, M. Use of $r b c L$ sequences for DNA barcoding and authentication of plant drugs used in Traditional Chinese Medicine. PeerJ PrePr. 2014, 2, e196v1. [CrossRef]

20. Tamura, K.; Nei, M. Estimation of the number of nucleotide substitutions in the control region of mitochondrial DNA in humans and chimpanzees. Mol. Biol. Evol. 1993, 10, 512-526. [PubMed]

21. Kumar, S.; Stecher, G.; Tamura, K. MEGA7: Molecular Evolutionary Genetics Analysis version 7.0 for bigger datasets. Mol. Biol. Evol. 2015. submitted. [CrossRef] [PubMed]

22. National Committee for Clinical Laboratory Standards (NCCLS). Methods for Dilution Antimicrobial Susceptibility Tests for Bacteria that Grow Aerobically; NCCLS: Wayne, PA, USA, 2006.

23. Shukla, H.S.; Tripathi, S.C. Antifungal substance in the essential oil of anise (Pimpinella anisum L.). Agric. Biol. Chem. 1987, 7, 1991-1993. [CrossRef]

24. Shukla, H.S.; Dubey, P.; Chaturvedi, R.V. Antiviral properties of essential oils of Foeniculum vulgare and Pimpinella anisum L. Agronomie 1989, 9, 277-279. [CrossRef] 
25. Pourgholami, M.H.; Majzoob, S.; Javadi, M.; Kamalinejad, M.; Fanaee, G.H.; Sayyah, M. The fruit essential oil of Pimpinella anisum exerts anticonvulsant effects in mice. J. Ethnopharmacol. 1999, 66, 211-215. [CrossRef]

26. Lazarević, J.; Radulović, N.; Palić, R.; Zlatković, B. Chemical analysis of volatile constituents of Berula erecta (Hudson) Coville subsp erecta (Apiaceae) from Serbia. J. Essent. Oil. Res. 2010, 22, 153-156. [CrossRef]

27. Andriamaharavo, N.R. Retention Data; NIST Mass Spectrometry Data Center: Gaithersburg, MD, USA, 2014.

28. Nadaf, M.; Nasrabadi, M.; Halimi, M. GC-MS analysis of n-hexane extract from aerial parts of Salvia nemorosa. Middle East J. Sci. Res. 2012, 11, 1127-1130.

29. Askari, F.; Sefidkon, F.; Mozafarian, V. Essential oil composition of Pimpinella aurea D.C. from Iran. Flavour Fragr. J. 2005, 20, 115-117. [CrossRef]

30. Stahl, E.; Herting, D. Die Verteilung von Inhaltsstoffen in drei Pimpinella-Arten. Phytochemistry 1976, 15, 997-1001. [CrossRef]

31. Reichling, J.; Merkel, B.; Hofmeister, P. Studies on the biological activities of rare phenylpropanoids of the genus Pimpinella. J. Nat. Prod. 1991, 54, 1416-1418. [CrossRef] [PubMed]

32. Wink, M. Modes of action of herbal medicines and plant secondary metabolites. Medicines 2015, 2, $251-286$. [CrossRef]

33. Marcetić, M.; Bozić, D.; Milenković, M.; Lakusić, B.; Kovacević, N. Chemical composition and antimicrobial activity of essential oil of different parts of Seseli rigidum. Nat. Prod. Commun. 2012, 7, 1091-1094. [PubMed]

34. Herrmann, F.; Hamoud, R.; Sporer, F.; Tahrani, A.; Wink, M. Carlina oxide-a natural polyacetylene from Carlina acaulis (Asteraceae) with potent antitrypanosomal and antimicrobial properties. Planta Med. 2011, 77, 1905-1911. [CrossRef] [PubMed]

(c) 2016 by the authors; licensee MDPI, Basel, Switzerland. This article is an open access article distributed under the terms and conditions of the Creative Commons Attribution (CC-BY) license (http://creativecommons.org/licenses/by/4.0/). 